\title{
ハイドロキシアパタイト人工血管の開発に関する実験的研究
}

\author{
过 隆之・青木秀希・宗岡克樹・秦＼cjkstart美治・戸川達男 \\ (東京医科菌科大学 医用器材研究所)
}

\section{Development of a Vascular Access Tube Made of Sintered Hydroxyapatite Tubing}

\author{
Takayuki TSUJI, Hideki AOKI, Katsuki MUNEOKA, Yoshiharu SHIN and Tatsuo TOGAWA \\ $\left(\begin{array}{l}\text { Institute for Medical and Dental Engineering, Tokyo Medical and Dental University } \\ \text { 3-10, Kanda Surugadai 2-chome, Chiyoda-ku, Tokyo } 101\end{array}\right)$
}

A vascular access tube made of sintered hydroxyapatite tubing was developed by animal experimentation. Anticoagulability of a tube, $3.8 \mathrm{~mm}$ in internal diameter and $2.0 \mathrm{~cm}$ long and made of sintered hydroxyapatite, was tested by insertion in the jugular vein of nonheparinized dogs under anesthesia. If patency lasted over $2 h$, the test was ended by venous occlusion. The patent time was longer for the tubes $(106 \pm 35 \mathrm{~min})$ pretreated by $24 \mathrm{~h}$ incubation in autologous heparinized plasma at $37^{\circ} \mathrm{C}$ and for those $(102 \pm 36 \mathrm{~min})$ implanted subcutaneously one week earlier in the abdominal wall of the recipient dog than for those $(46 \pm 30 \mathrm{~min})$ treated by dipping in autologous heparinized blood for $5 \mathrm{~min}$. The mean shear rate and activated coagulating time were not significantly different among the three groups. No rupture or pseudoaneurysm was observed in 15 dogs in which 26 tubes of 2.6-2.8 mm internal diameter were implanted in the carotid arteries and jugular veins when they were examined at an average of 2 months after implantation. In one dog, the tube $2.5 \mathrm{~mm}$ in internal diameter in a carotid artery was revealed angiographically to be patent on the 85 th day after implantation. It is concluded that appropriate pretreatment can make sintered hydroxyapatite more biologically compatible and the use of its tubes an excellent blood means of access.

[Received February 18, 1987 ; Accepted April 21, 1987]

Key-words : Bioceramics, Hydroxyapatite, Vascular access, Anticoagulability, Aortic aneurysm

\section{1. 緒言}

現状の人工血管はすべて高分子材料である. 血管が柔 軟であるので人工血管もそのようにあらねばならないと いう考えからである. それに対して著者らが今回人工血 管に用いようとする材料はハイドロキシアパタイトであ る. バイオイナートなセラミックスが抗血栓性に優れて いることはすでに臨床でパイロライトカーボンが人工弁 として用いられていることでもよく知られている1.

それに対してバイオアクティブなセラミックスである 八イドロキシアパタイトは, 特に生体親和性のよいこと で知られ, 骨充填材, 人工歯根として現在ヒトに用いら れている ${ }^{2)}$. 著者ら ${ }^{3)}$ はその緻密体中空管を用いそれを 人工血管とするた䡃物実験を行ってきた，本論文では ハイドロキシアパタイト中空管に前処置を加え, その抗 血栓性を急性実験でテストして検討した結果について述 ベ，さらに臨木応用への可能性について言及したい。

\section{2. 実 験}

相対密度がほぼ $95 \%$ の緻密体ハイドロキシアパタイ トで, 長さ $20 \mathrm{~mm}$, 外径 $5.0 \mathrm{~mm}$, 内径 $3.8 \mathrm{~mm}$ の中空 管を 36 本作製した. 断端は鋭い鋭角を避けただけで特 別に加工しなかった. 雑犬 18 頭を対象とした. ケタラー ルおよびペントバルビタール併用麻酔で気管挿管して調 節呼吸下においたイ又の頸静脈を露出し，血管遮断鉗子
で血管の上下を遮断し 1 個所に切開を加えた. 血管内腔 の血液を生理食塩水で洗い流した後,アパタイト中空管 を頸静脈に挿入し, 両端を結紮して血流を再開した. イ 又には抗凝固剤（ヘパリン）を投与しなかった。 アパタ イト管が血栓で閉塞するまでの時間を超音波流量計 (Transonic Systems Inc. 製，T 101) で血流量を計測 し, ペン型記録計 (理化電気製, R-104/102) で記録し て, 血流量がゼロとなった時を閉塞した時点とした。 ま た 2 時間たっても開存しているものについてはその時点 で頸静脈を遮断し，テストを終了した（図１）.ささらに 大腿動脈からテス・卜中に採血し, 凝固能 (ACT：Ac-

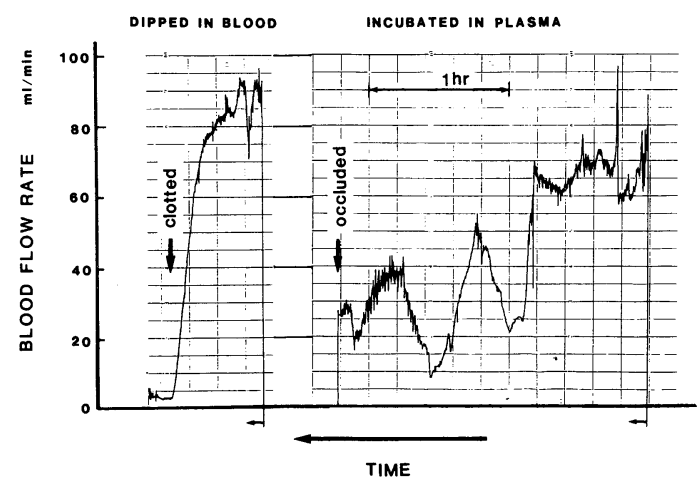

Fig. 1. Representative recordings of the flow measurements. 
tive Coagulating Time or Activated Clotting Time) をへモクロン 400 (テクニダイン製) で計測した. 1 頭 のイヌで左右頸静脈について順次行った.

イヌを 6 頭ずつ 3 群に分けた。 I 群 12 本ではへパリ ン化自家血（ヘパリン 2 単位/自家血 $1 \mathrm{ml}$ ) に 5 分間 浸した（プレクロッティング）後，テストした。 II 群 12 本では植え込み 1 週間前に自己の腹壁皮下に前もっ て植え込み, テスト時に取り出して, 同一犬でテストし た。 III群 12 本ではヘパリン化自家血漿（ヘパリン 2 単 位／自家血漿 $1 \mathrm{ml}$ ) で $37^{\circ} \mathrm{C}$ でドライバス（サーモニク ス製，D 37-12 B) で 24 時間インキュベートし，それ を同一犬でテストした.ずり速度と開存時間の関係を各 群について検討した。

さらに処理前，インキュベーション後および皮下埋没 後のアパタイト中空管の内面を走査型電子顕微鏡 (SEM) で観察した.

\section{3. 結 果}

プレクロッティング群 ( I 群), 腹壁皮下埋没群 ( II 群 $)$
およびインキュベーション群（林群）についてのイヌ体 重, 凝固能, 開存時間, 最大および平均流量, 最大およ び平均ずり速度の結果は表 1，2，3のようであった。開 存時間は I 群がII, III群に比べ短かった. イヌの体重, $\mathrm{ACT}$, 血流量, ずり速度に 3 群間で有意の差がなかった. 3 群について平均ずり速度と開存時間との関係を図 2,3, 4 に示した。すすねち，プレクロッティング群 (口) が 腹壁皮下埋没群 $(\Delta)$ とインキュベーション群 $(O)$ に 比べて有意に短時間に閉塞し，2 時間以上開存した例は 1 例（ロ）のみであり，最高，平均ずり速度は開存時間 には無関係であった. II 群と III群に 2 時間以上開存した 例（二，○）が多くみられたが，平均值で比較すると図 5 のように両群間に有意差はなかった.

2 時間以上開存したものは I 群で $8 \%$ ( $1 / 12$ 本), II 群で $50 \%$ (6/12 本) および四群で $58 \%$ (7/12 本) であっ た. 2 時間以上開存した例とそれより短時間で閉塞した 例を II， III群で分けて，ずり速度を検討すると表 4 のよ うであった。すなわち，開存時間が 2 時間以上の群につ いて最大, 平均ずり速度が大きい傾向がみられるが，皮

Table 1. Parameters for 12 tubes in group $I$.

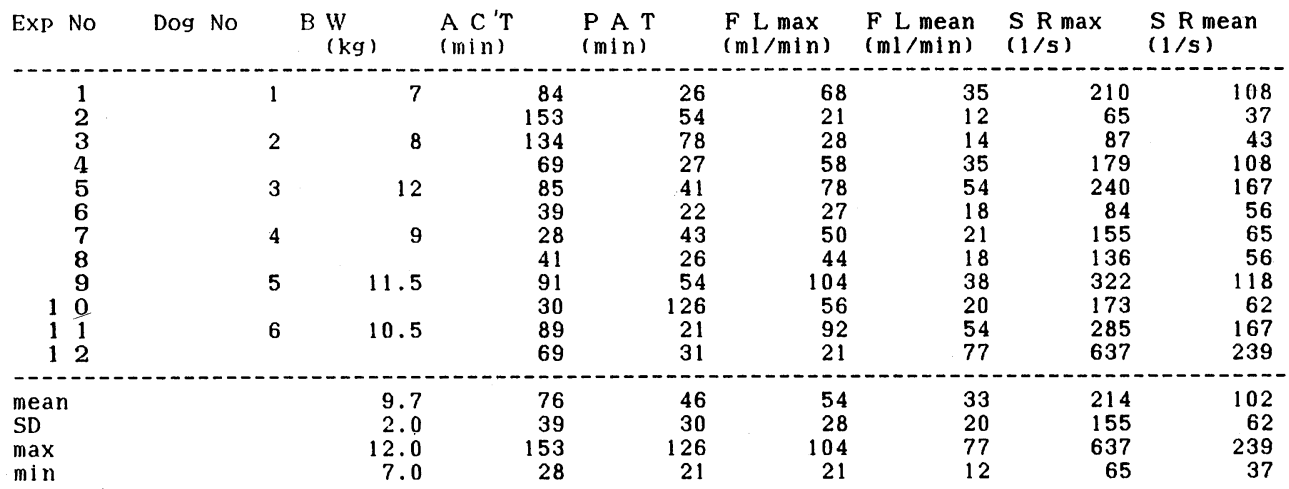

Abbreviations :

SD : standard deviation $; \max :$ maximal $; \min : \operatorname{minimal} ; \mathrm{BW}:$ body weight $; \mathrm{ACT}:$ activated clotting time ; PAT : patent time ; $\mathrm{FL}_{\max }$ : maximal flow rate; $\mathrm{FL}_{\text {mean }}$ : mean flow rate $\mathrm{SR}_{\max }$ : maximal shear rate $; \mathrm{SR}_{\text {mean }}$ : mean shear rate

Table 2. Parameters for 12 tubes in group II.

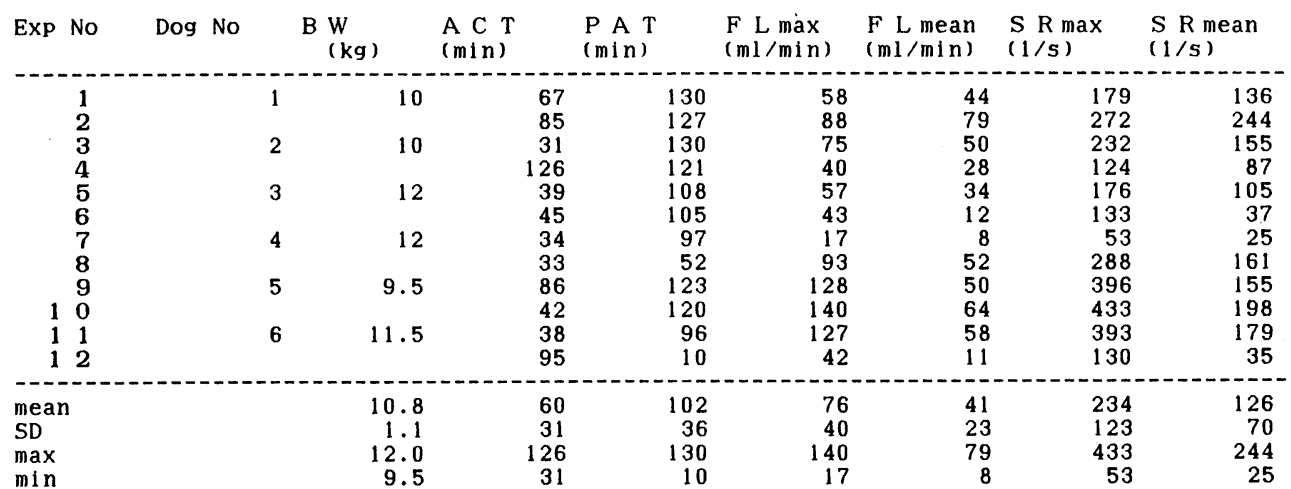

For abbreviations, see the footnote to Table 1 . 
Table 3. Parameters for 12 tubes in group III.

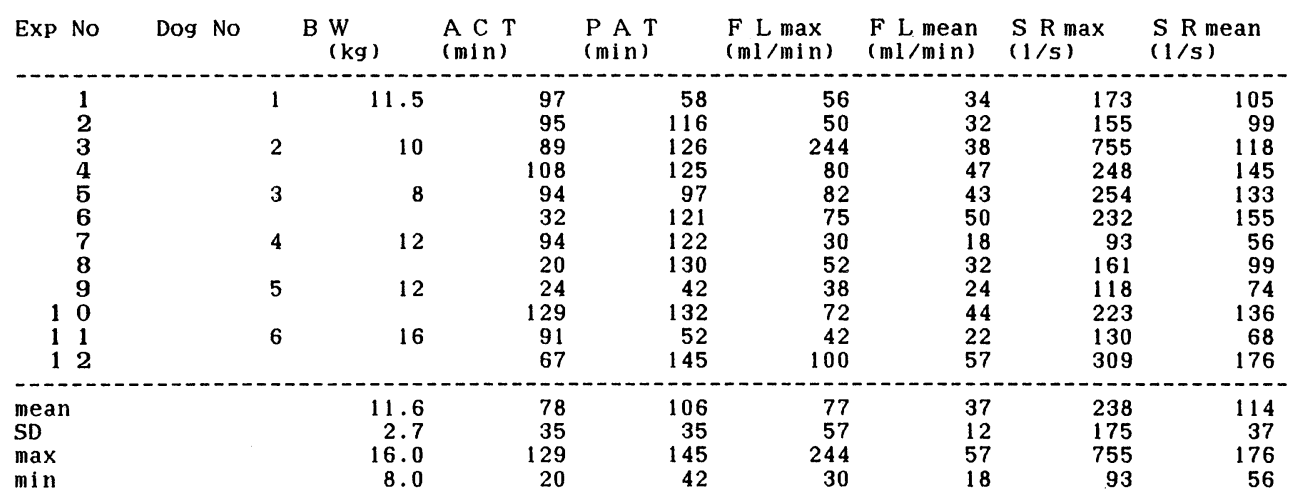

For abbreviations, see the footnote to Table 1 .

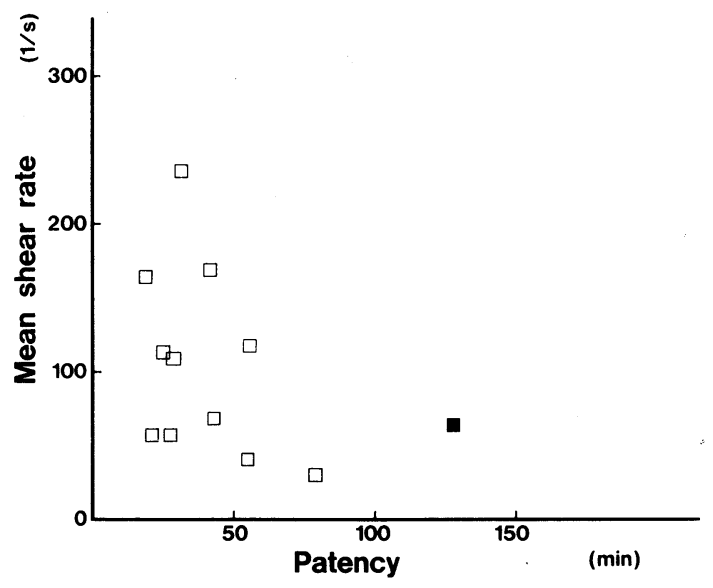

Fig. 2. The relationship between mean shear rate and patency in group $I$ in which the tube was dipped for 5 $\min$ in heparinized blood before the test.

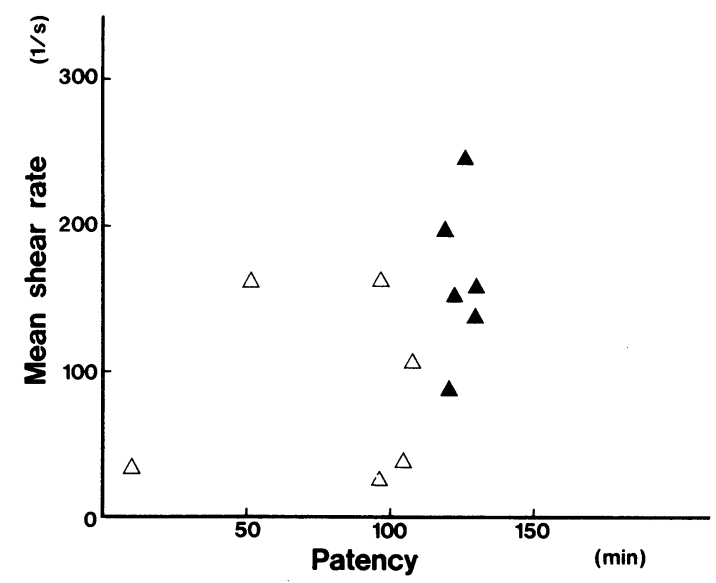

Fig. 3. The relationship between mean shear rate and patency in group II in which the tube was implanted subcutaneously into the abdominal wall of the recipient dog one week before the test.

下埋没群（II 群）で開存時間が長い場合には平均ずり速 度が有意に大きい関係が認められた。

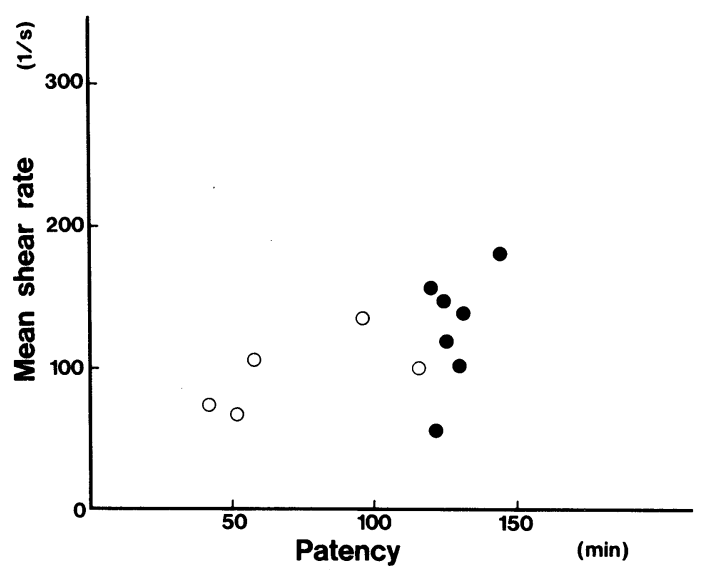

Fig. 4. The relationship between mean shear rate and patency in group III in which the tube was incubated for $24 \mathrm{~h}$ in heparinized autologous plasma preceding the test.

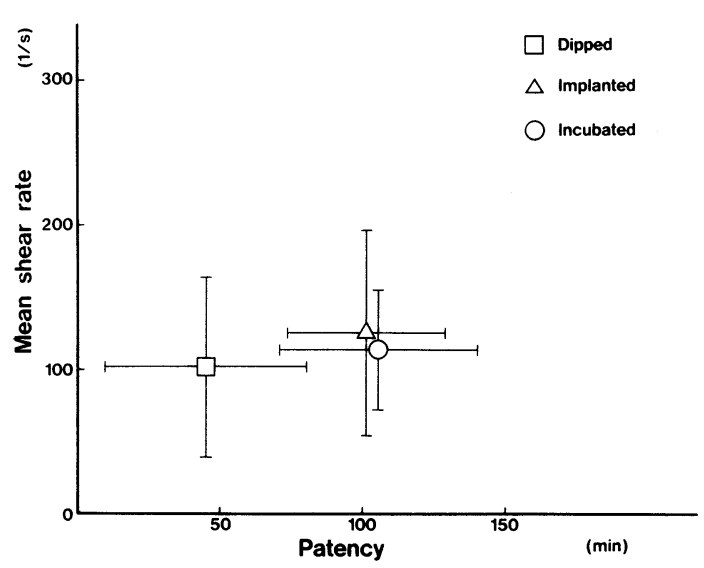

Fig. 5. The relationship between the mean values of the mean shear rate and the mean patent time in groups I, II and III.

処理前, インキュベーション後, 腹壁皮下埋没後のお のおのの内面の SEM 像は図 6, 7,8 のようであった. 
Table 4. The comparison of the parameters in the tubes with patency less and more than $2 \mathrm{~h}$ in groups II and III.

Group II

\begin{tabular}{|c|c|c|c|c|}
\hline Patent time & $(m 1 n)$ & $120\rangle$ & \rangle$=120$ & \\
\hline n & & 6 & 6 & \\
\hline patency & $(m \mid n)$ & $78 \pm 39$ & $125 \pm 4$ & $\mathrm{p}<0.01$ \\
\hline SRmax & $(1 / 5)$ & $196 \pm 124$ & $273 \pm 121$ & ns \\
\hline SRmean & $(1 / 5)$ & $90 \pm 68$ & $163 \pm 54$ & $p<0.05$ \\
\hline ACT & $(\mathrm{min})$ & $47 \pm 24$ & $73 \pm 34$ & ns \\
\hline
\end{tabular}

\begin{tabular}{lcccc} 
& \multicolumn{5}{c}{ Group III } \\
Patent time & $(\mathrm{m} / \mathrm{n})$ & $120>$ & $>=120$ & \\
\hdashline $\mathrm{n}$ & $(\mathrm{min})$ & $73 \pm 32$ & $129 \pm 8$ & $\mathrm{p}<0.01$ \\
patency & $(1 / \mathrm{s})$ & $166 \pm 54$ & $288 \pm 216$ & $\mathrm{~ns}$ \\
SRmax & $(1 / \mathrm{s})$ & $96 \pm 26$ & $126 \pm 40$ & $\mathrm{~ns}$ \\
SRmean & $(\mathrm{min})$ & $80 \pm 30$ & $77 \pm 40$ & $\mathrm{~ns}$ \\
ACT & & & &
\end{tabular}

For abbreviations, $n$, number of tubes, ns, not significant; for others. see the footnote to Table 1 .

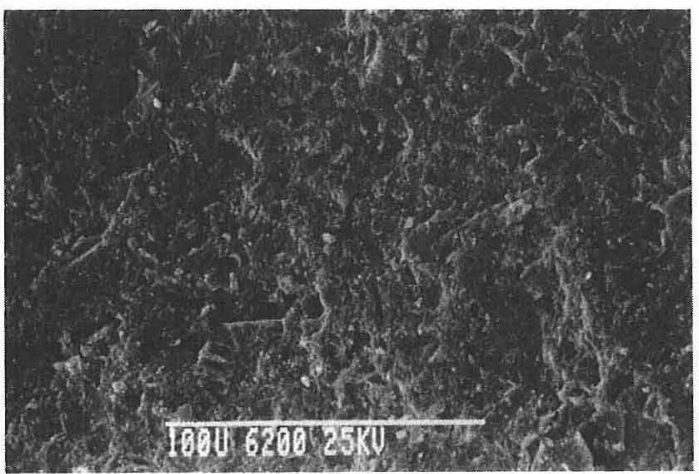

Fig.6. Scanning electron micrograph of the inner surface of a sintered hydroxyapatite tube without any pretreatment.

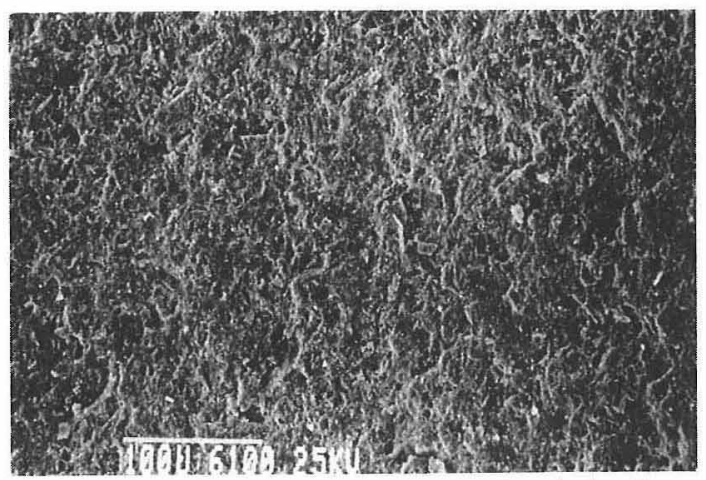

Fig. 7. Scanning electron micrograph of the inner surface of the tube incubated at $37^{\circ} \mathrm{C}$ for $24 \mathrm{~h}$ in autologous heparinized plasma. The surface seemed to be almost the same as that of an untreated tube.

\section{4. 考 察}

セラミックスのみならず生体材料の抗血栓性のテスト 法にはいまだ標準的な方法がない，生体材料を人工血管

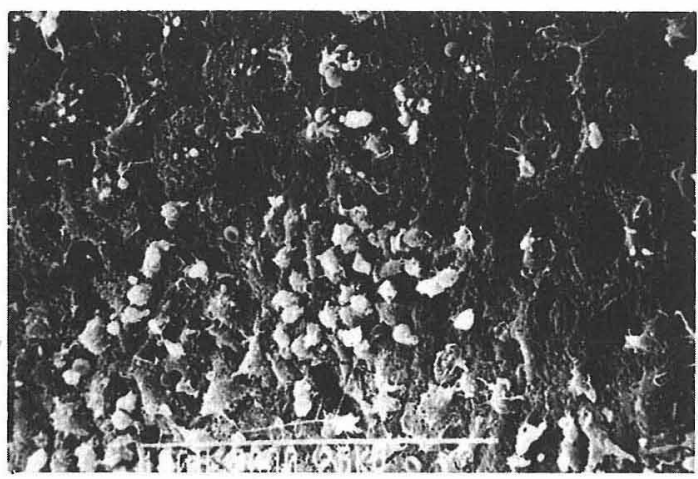

Fig. 8. Scanning electron micrograph of the inner surface of a tube implanted for one week subcutaneously in the abdominal wall of the recipient dog. Many blood components are observed adhering to the surface of the tube.

に用いようとする場合には，動物の血管に植え込み，長 期に飼育して開存を観察する方法が現状では一般的であ る. セラミックスの抗血栓性に関しては本邦では三田村 ら ${ }^{4)}$ の報告がある.それは下大静脈にテスト材料を一定 形状の中空管にして留置し，一定期間後に取り出して血 栓形成を調べる方法である. 三田村らの検討ではアパタ イトより単結晶アルミナセラミックスのほうが抗血栓性 に優れているとされている.

著者ら ${ }^{3)}$ はすでに何ら前処置をしていないハイドロキ シアパタイト中空管についてイヌを用いて慢性実験で抗 血栓性を検討した. すなわち平均内径 $2.3 \sim 2.5 \mathrm{~mm}$, 平均長さ 15.6 30.8 mm の中空管 26 本をイヌ 15 頭の 頸部血管 (頸動脈 15 本, 頸静脈 11 本) に留置して平均 2 個月観察した後摘出した. その間， 1 例も死亡せず血 管破裂や仮性動脈瘤など血管損傷を来した例はなく，本 
中空管は生体のみならず血管に対しても安全であること を確認した．うち 1 例に内径 $2.5 \mathrm{~mm}$ の中空管が頸動脈 で (図 9), 内径 $2.4 \mathrm{~mm}$ の中空管が顓静脈で 85 日めに もなお開存しているのを血管造影で確認した.

しかしそれらの方法（慢性実験）では開存率が材料の 性質以外の植え込み手術手技や感染などの影響を免れな いし，どのように血栓が形成されつつあるかも正確には 観察できず，ある一定期間後の結果しか分からない，そ れに対して今井らの方法(5)ではもっと簡便に抗血栓性を 短時間でテストできる. 本法によればテス卜材料ででき た小口径の中空管を，イヌになんら抗凝固剤を投与しな いで流速が遅く血圧の低い頸静脈内に留置する.した がって，血液は管内で㠜固しやすく，血栓は管腔を閉塞 しやすいのでテスト材料の抗血栓性を短時間に検出でき る.

血栓は血流の速度, 血管壁の状態, 血夜の性状できま るといわれている，すなわち血流速度が遅く，血管壁の 性状が血小板が付着しやすく, また血液自身が凝固しや すければ，血栓ができやすい．人工血管にしようとする 材料の抗血栓性は血液に接する部分の抗血栓性であるか ら, 材料に接する部分の血流速度と血液の凝固性とが制 御されていないと, 各材料の抗血栓性を相互で比較する ことはできない，しかしそれを実際の生体で制御するこ

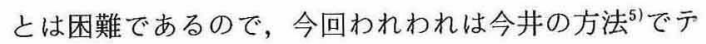
ストを行い, 新しく開発された原理（トランジットタイ ム法) に基づく超音波流量計6)で, 内圧によっては压平 する静脈の血流を正確に計測してテストチューブ内での ずり速度を算定し，同時に血液の凝固性を反映するパラ メーターも計測して実験結果の解析を試みた.

その結果, 血液の凝固能を ACT (凝固能が高まると その值が短縮し，ヘパリンを投与すると延長する）で評 価すると，いずれの群間でも值に有意差がなかった。す なわち血液の凝固能には 3 群間で差がなかった．血管壁

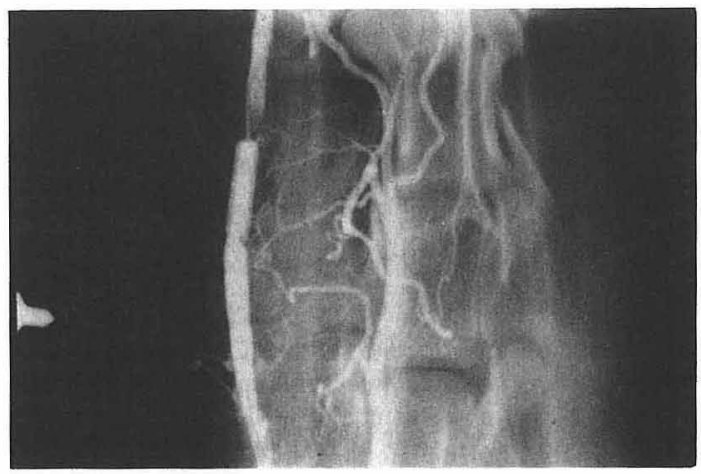

Fig. 9. A tube, $2.5 \mathrm{~mm}$ in internal diameter, implanted into the canine carotid artery. The tube was patent angiographically on the 85 th day after implantation.
からみた血液の速度はずり速度として表現されるので本 研究ではそれを求めたところ, 3 群間に有意差がなかっ た．すなわち，3 群間で血液の性状と流速には有意の差 がなかった．しかし，プレクロッティング群は他の 2 群 より明らかに開存時間が短かった。したがって, 人工血 管壁の性状がプレクロッティング群と他の 2 群とでは異 なるといえる，ずり速度と開存時間との関係で比較する とプレクロッティング群ではずり速度が大きくても開存 時間は短い例もあり，両者は無関係ではあるが，皮下埋 没群では開存時間が長い例ではずり速度も大きい傾向を 示した。

以上の結果からハイドロキシアパタイトは適切な前処 置をすることによってより抗血栓性を獲得したと考えら れる．アパタイトは蛋白成分を吸着する ${ }^{7) 8 \text {. }}$. プラズミ ノーゲンアクチベータ（線溶系活性酵素）を吸着すると いう報告もある ${ }^{9}$. 自己組織や自己血液成分に前もって 接触させると抗血栓性の向上を示すのは合理的な結果で あろう。

腹壁皮下埋没群ではSEM 像で内腔表面に血球成分な ぞが多数沈着しているのが観察された.しかし,インキュ ベーション群のそれは処置前の内腔表面の SEM 像とほ とんど差がなかった。したがって, 開存性は両群間に差 がないので処理操作の簡単さや管内血栓を誘導するよう な血球成分の壁沈着がないことからへパリン化血漿によ るインキュベーション法がそれを実際にヒトに用いる場 合には適切であろうと考えている.

アパタイトは高歯者で大動脈壁にしばしば見られる石 灰沈着と成分は同じものである. 本人工血管は剛管であ ることが実際の血管と著しく異なっているが，血管材料 としては異常なものではない, 大動脈瘤は欧米で, また 高齢者に多い疾患である. したがって, 食生活の変化や 高齢者の増加で大動脈瘤患者は本邦でも増加しつつあ る. 大動脈瘤を切除してその間に人工血管を縫着する手 術は侵襲が大きい，また手術時間も長く十数時間を要す る場合もある. そのために, 従来の高分子材料の人工血 管の両端に金属を布で覆ったリングを付けたリング付き グラフト ${ }^{10}$ が最近本邦でも用いられ始めている ${ }^{11}$. リン グを動脈瘤切除後の大動脈断端に挿入固定するだけでよ いので，手術時間が短縮できる．しかし，リングが金属 であるため血管との接合部で血管壁の損傷が起こって, 出血や仮性動脈瘤などを合併する症例のあることが知ら れている.

アパタイトは金属を覆った布よりも血管に対して適合 性がよいと考えられるので, アパタイトがそのリングに 用いられる可能性は高い. 現在のリング付きグラフトは 長さがきまった既製品なので, グラフトの途中を切断し 吻合して長さを調節する，それに対して本法によれば大 動脈瘤切除後の両断端にアパタイトリングを挿入し結杽 


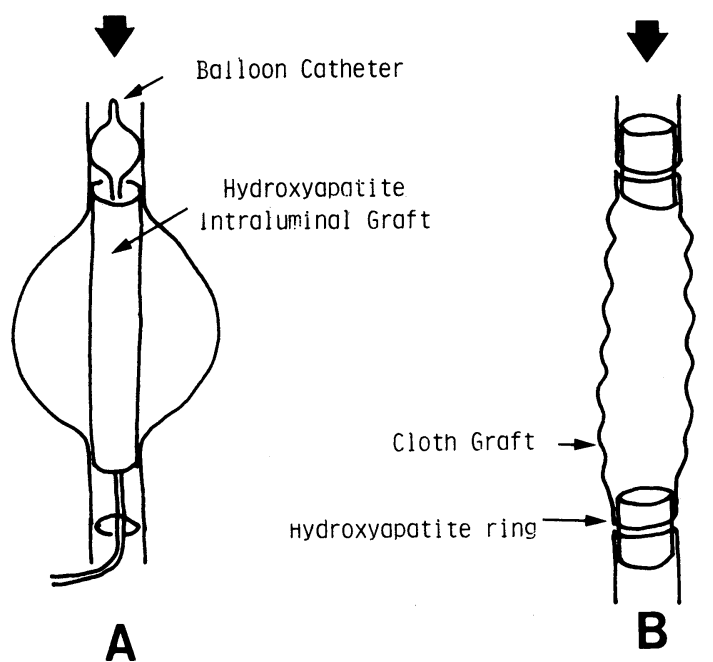

Fig. 10. A schematic drawing of the use of the tube for an intraluminal graft $(A)$ and the ring of a ringed graft (B).

固定する．その間を従来の人工血管を適当に切って挿入 し，それをリングと結紮固定するので血管吻合操作を全 く必要としない（図10 (B)).さらには著者らは内挿 型の人工血管を目指している(図 $10(\mathrm{~A}))$.

以上のように著者らは高齢者や合併症を有する大動脈 瘤症例に対する姑息的手術に用いるために本人工血管を 開発している ${ }^{12)}$ 。それを用いれば大動脈瘤の切除も血管 吻合も不要となる.大動脈は身体のもっとも深い部分(胸 腔, 腹腔) にあるので, 通常の外力によって大動脈内の セラミックス管は破壊されることはない，本材料は新し い vascular access として有用であろう.

カーボン系のセラミックスは抗血栓性に優れているが 全く生体と反応しない，現在著者らはカーボン系セラ ミックスの外面をアパタイトコーティングした中空管も 同様の方法でイヌに植え込んで検討している，セラミッ クスの複合材料化である. 前処置しなくても抗血栓性が よく, さらに血管に対してはアパタイトの優れた生体適 合性を発揮させようとするものである．いずれが人工血 管として有用かは性能のほかにコストの問題も重要であ ろう.

\section{5. 総 括}

今回著者らは 36 本のハイドロキシアパタイト緻密焼
結体中空管に対し，雑犬 18 頭を用い，プレクロッティ ング，ヘパリン化自己血漿インキュベーションおよび自 己腹壁皮下埋没処理を各 12 本, 6 頭ずつについて行っ て，それらをイヌ頸静脈に挿入留置し，ずり速度と血液 の凝固能を同時に計測してその開存性を 2 時間以内でテ ストした。 その結果, ずり速度と凝固能に 3 群間で差が ないにもかかわらず，プレクロッティング群より，へパ リン化自己血漿インキュベーション群および自己腹壁皮 下埋没群のほうが明らかに開存時間が長く, 皮下埋没群 ではずり速度が大きくなるにつれて開存時間が延長する 傾向を認めた。すなわち，前処置によって本材料が抗血 栓性を獲得することを明らかにした. さらに 15 頭のイ 又の頸動静脈に何ら前処置しない中空管 26 本を植え込 み飼育したところ，1例も死亡せず，血管の破裂，出血 なども観察されなかっだ!.

したがって本材料は血管に対して安全であり，大動脈 瘤の治療に用いる人工血管として応用できると考えられ た。

(本研究の一部は第 2 回アパタイト研究会 (1987 年) で発表した. )

\section{文献}

1) F. J. Schoen, J. L. Titus and G. M. Lawrie, J. Biomed. Mater. Res., 16, 559-70 (1982).

2）牧島亮男，青木秀希，“バイオセラミックス”，技報堂出 版 (1984).

3) 辻 隆之, 青木秀希, 秦 美治, 宗岡克樹, 東方正章, 大内成美, 請川 洋, 戸川達男, 人工藏器, 14, 671-74 (1985).

4）三田村好矩，立木利一，牧野秀夫，三上智久，北村安弘, 生体材料，2，151-56 (1984).

5）今井庸二, 渡辺昭彦, 増原英一, 人工臓器, 2, 95-101 (1973).

6) R. G. Burton and R.C. Gorewit, Medical Electronics, 68-73 (1984)

7）青木秀希, 秦 美治, 臨整外, 21, 1225-32（1986）.

8) C. P.A. T. Klein and K. de Groot, J. Biomed. Mater. Res., 14, 705-12 (1980).

9) 真田 進, 椙江 勇, 丹羽滋郎, 早坂孝則, 竹内啓泰, Transactions of the Second Symposium on Apatite, 第 2 回アパタイト研究会 (1987) pp. 85-86.

10) S.G.G. Ablaza, S. C. Ghosh and V.P. Grana, J. Thorac. Cardiovasc. Surg., 76, 390-96 (1978).

11）東館雅文, 高梨吉則, 今井康晴, 日胸外会誌, 35, 13-25 (1987)

12）辻 隆之，材料フォーラム， 5, 21-24（1986). 